\title{
The Microbiological Quality of Commercial Fruit Juices-Current perspectives
}

\author{
Tasnia Ahmed ${ }^{1}$, Kamal Kanta Das ${ }^{1}$, Md. Aftab Uddin ${ }^{1 *}$ \\ ${ }^{1}$ Department of Microbiology, Stamford University Bangladesh, 51 Siddeswari Road, Dhaka-1217, Bangladesh.
}

\begin{abstract}
The purpose of this review article is to introduce the importance of fruit juices for human health living in the country and in a broad, and to develop awareness among the people about the diseases caused by pathogens associated with fruit juice. Health benefits of juices have been included in this article and how the same juice can cause problems among people of different ages have been discussed. Contamination sources and the ways to prevent them is very important issue in protecting public health Some future recommendations for fruit juices have also been added in this article. Different diseases caused by various microbial agents and the associated symptoms after consuming contaminated fruit juices worldwide are discussed in this review. This review was aimed at the possible sources of microbial contamination, disease caused by them and determining some ways to avoid such phenomena. From the information provided here, it was noticeable that commercial fruit juice can also harbor pathogenic microorganisms which can cause serious disease outbreaks. The contamination can also be initiated during in house consumption if lack of awareness prevails among the consumers. Manufacturing process should be much more strict in this regard to assure the public health safety. Commercially available fruit juices are consumed worldwide among different ages of people and if not processed properly, this healthy drink may be hazardous for human health.
\end{abstract}

Keywords: Fruit juice, Contamination, Microbial spoilage, Public health safety, Good manufacturing practice (GMP).

\section{Introduction to fruit juices and the nutritional values}

Fruit juice is a popular soft drink made of the pulp of different types of fresh fruits ${ }^{1-4}$. Fruit imparts natural flavour to fruit Fruit juices contain many components which are beneficial for our health. Though the actual components varies from fruits to fruits, in general they contain flavonoid glycosides, dietary fiber, calcium, vitamin C, carotenoids, lutein, lycopene, ${ }^{2}$-carotene, phenolic acids, stilbenes, ellagic acid, amino acids, aroma compounds, anthocyanin, flavonols, polyphenols, potassium, vitamin D, low amount of sodium, cholesterol, fat etc. Components present in fruit juices has been proved to help in preventing heart disease, certain cancers, diabetes, cataracts, Alzheimer's disease, asthma and helps in the formation of collagen, cartilage, blood vessels and muscles ${ }^{5-23}$. Considering those beneficial impacts on human health, fruit juices become popular worldwide.

\section{Global availability of packed juices and the consumers}

People of all ages like to drink fruit juices. Young children who drinks fresh fruits or juices regularly, can maintain the habit till the age of adolescence. Regular fruit juice drinkers have been shown to suffer less chronic illnesses ${ }^{23,24}$. Due to worldwide available transportation systems commercially produced fruit juices have been transported from country to country for making the juice products available everywhere. Fruit juices are more popular among children,. but adults used to drink other carbonated soft drinks and/or other energy drinks rather than fruit juices, though most of the cases they have no benefit on heath. People who drink more fruit juices have better health conditions, better immune system comparing those who don't drink fruit juices. Fresh fruit juices without additives and extra sugar are more healthy and have no harmful effects on health. Juice which contains other added ingredients and high sugar contents may damage our health.

High earning and educated people like to drink fruit juice as a supplement of vitamins and other essential nutrients for health, but low earning people unable to afford money to buy fruit juices. School going children also prefer juices due to their attractive freshness and many flavors as well as the attractive packaging specially manufactured for them ${ }^{25-32}$.

\section{Microbiological quality perspective of packed juice}

Commercial fruit juices can be prepared either by pasteurization or by adding chemical preservatives. Processed fruit juices rather than pasteurization are more popular due to their fresh tastes. In the industry fruit juice is processed by automatic machine (collection, cleaning, extraction of juices and packaging). There is en every possibility of contamination of processed fruit juice at any stage of processing. Cotamination may be occurred by spoilage organisms and/or by food borne pathogens. Food borne 
disease outbreaks have been documented in different countries ${ }^{33-}$ 37. Specially Yeast and molds are the dominant microorganisms in juice because they can thrive the high acidic conditions of the juice. Some examples of them are species of the genera Cladosporium, Candida, Dekkera, Pichia, Saccharomyces, Aspergillus, Zygosaccharomyces, Penicillium, Byssochlamys, Hanseniaspora, Paecilomyces, Mucor, Fusarium, Botrytis, and Neosartorya Talaromyces etc. Some lactic acid and acetic acid bacteria may be present in fruit juices. Some pathogenic bacteria like Escherichia coli O157, Salmonella, and Cryptosporidium, fecal Streptococci and some spore formers like Clostridium pasteurianum and Bacillus coagulans may be present in fruit juice if the juice is not processed adequately. ${ }^{38-51}$.

Bacterial growth in fruit juice depends on $\mathrm{pH}$, storage temperature, types of packaging material, humidity, water activity, concentration of preservatives, application of UV treatments during production, sugar contents, quality of water used in juice, quality of the machines used in the juice industries, raw materials, quality of fruits etc. Mainly improper washing of fruits with poor quality water used in the juice preparation are the major source of contaminating microbes found in the fruit juices ${ }^{52-59}$. Some fruit juice spoiling organisms are listed in Table 1.

Fruit juices are stored in cold temperature and/or in normal temperatures. When packed juices are kept in humid condition and at ambient temperatures (for example during summer seasons), spoiling microorganisms often get stimulated to grow and cause spoilage and change in odor, taste, visual change etc. If the packaging is not enough protective, they may invite the spoilage causing microbes to get entrance and spoil the drinks. Smaller packages are consumed instantly after opening and have less chance of contamination during consumption. But in case of larger packages, juice pack is often stored in normal temperature or refrigerators depending on the users, which may be more vulnerable for contamination.

High pressure, UV radiation, Gamma radiation, ozonization, electron beam radiation, pasteurization, pulsed electric ofield processing etc. and chemical preservatives such as organic acids, hydrogen peroxide, dimethyl dicarbonate, vanillin, monocaprylin, essential oils, vanillic acid, nisin and cinnamon etc are to be applied to preserve fruit juice ${ }^{65-68}$.

\section{Fruit juice associated disease outbreaks}

Food borne pathogens if present at sufficient number in fruit juice may cause illness in the consumers. Some microbes only survive in the juice and multiply within the host after consumption and start the disease. Some microbes which can multiply within the juice may yield off odor in juice and make juice unfit for human consumption. Clostridium perfringens, Staphylococcus aureus, Bacillus cereus, Clostridium botulinum able to produce toxins in fruit juice and after drinking the juice can cause food poisoning. Fruit juice contaminating pathogens and symptom caused by them are listed in Table 2.

Table 1. List of microorganisms responsible for spoilage $e^{60-64}$

\begin{tabular}{|c|c|c|c|}
\hline \multicolumn{2}{|c|}{ Yeast } & Mold & Bacteria \\
\hline $\begin{array}{l}\text { Heat sensitive: } \\
\text { Pichia, } \\
\text { Candida, } \\
\text { Saccharomyces, } \\
\text { Rhodotorula, } \\
\text { Pichia membranifaciens, } \\
\text { Candida maltosa, } \\
\text { C. sake, } \\
\text { Saccharomyces bailii, } \\
\text { S. bisporus, } \\
\text { S. cerevisiae, } \\
\text { S. rouxii, } \\
\text { S. bayanus, } \\
\text { Brettanomyces intermedius, } \\
\text { Schizosaccharomyces pombe, } \\
\text { Torulopsis holmii, } \\
\text { Hanseniaspora guilliermondii, } \\
\text { Schwanniomyces occidentalis, } \\
\text { Dekkera bruxellensis, } \\
\text { D. naardenensis } \\
\text { Torulaspora delbrueckii, } \\
\text { Zygosaccharomyces } \\
\text { microellipsoides, } \\
\text { Candida parapsilosis, } \\
\text { C. stellata, } \\
\text { Torulaspora delbrueckii, } \\
\text { Zygosaccharomyces rouxii. }\end{array}$ & $\begin{array}{l}\text { Resistant to } \\
\text { preservatives: } \\
\text { Zygosaccharomyces } \\
\text { bailli, } \\
\text { Candida krusei, } \\
\text { Saccharomyces bisporus, } \\
\text { Schizosaccharomyces } \\
\text { pombe, } \\
\text { Pichia membranifaciens } \\
\text { Resistant to heat: } \\
\text { P. membranifaciens }\end{array}$ & $\begin{array}{l}\text { Heat resistant: } \\
\text { Byssochlamys fulva, } \\
\text { Neosartorya ficheri, } \\
\text { Talaromyces spp., } \\
\text { Paecilomyces } \\
\text { variotii, Aspergillus tamari, } \\
\text { A. flvus, A. ochraceus, B. } \\
\text { nivea. } \\
\text { Mycotoxin producers: } \\
\text { Byssochlamic acid } \\
\text { (Byssochlamys fulva, B. } \\
\text { nivea), patulin } \\
\text { (B. fulva, B. nivea, } P \text {. } \\
\text { expansum), ochratoxin } \\
\text { (Aspergillus } \\
\text { carbonarius), citrinin } \\
\text { (Penicillium expansum, } P \text {. } \\
\text { citrinum) }\end{array}$ & $\begin{array}{l}\text { Lactic acid bacteria: } \\
\text { L. mesenteroides ssp. cremoris, } \\
\text { Leuconostoc } \\
\text { paramesenteroides, } \\
\text { Leuconostoc dextranicum } \\
\text { Acetic acid bacteria: } \\
\text { Acetobacter, Gluconobacter, } \\
\text { and Gluconacetobacter } \\
\text { Alicyclobacilli: } \\
\text { Bacillus acidocaldarius, B. } \\
\text { acidoterrestris, Alicyclobacillus } \\
\text { acidocaldarius, A. hesperidium, } \\
\text { A. acidophilus, A. } \\
\text { cyclohaptanicus, A. fastidious, } \\
\text { A. pomorum } \\
\text { Others: } \\
\text { Propionibacterium } \\
\text { cyclohexanicum, Streptomyces } \\
\text { spp., Bacillus coagulans, B. } \\
\text { marcesens C. } \\
\text { pasteurianum and C. butyricum. } \\
\text { Pathogenic bacteria: } \\
\text { Escherichia coli, Salmonella } \\
\text { spp., Shigella spp., } \\
\text { Staphylococcus spp. }\end{array}$ \\
\hline
\end{tabular}


Table 2. Disease symptoms caused by contaminating microbes found in fruit juices ${ }^{69,70}$.

\begin{tabular}{|l|l|l|}
\hline Microorganisms & Examples & Disease symptoms \\
\hline Bacteria & Salmonella spp. & Abdominal pain, diarrhea, chills, fever, nausea \\
\cline { 2 - 3 } & Shigella spp. & Abdominal pain, diarr hea, fever, nausea \\
\cline { 2 - 3 } & Clostridium botulinum & $\begin{array}{l}\text { Nausea, vomiting, fatigue, dizziness, dryness of mouth and } \\
\text { throat, muscle paralysis, difficulty swallowing, double or } \\
\text { blurred vision. }\end{array}$ \\
\cline { 2 - 3 } & Escherichia coli 0157:H7 & $\begin{array}{l}\text { Bloody diarrhea, abdominal pain, hemolytic uremic } \\
\text { syndrome (HUS), kidney failure. }\end{array}$ \\
\cline { 2 - 3 } & Listeria monocytogenes & $\begin{array}{l}\text { Gastroenteritis, childbirth in pregnant women, septicemia, } \\
\text { meningitis. }\end{array}$ \\
\hline Virus & Hepatitis A & $\begin{array}{l}\text { Fever, malaise, anorexia, nausea, abdominal } \\
\text { pain, jaundice, dark urine }\end{array}$ \\
\cline { 2 - 3 } & Norwalk virus & $\begin{array}{l}\text { Vomiting diarrhea, mala ise, fever, nausea, abdominal } \\
\text { cramps }\end{array}$ \\
\hline Parasites & Cyclospora spp. & $\begin{array}{l}\text { Watery diarrhea, nausea, anorexia, abdominal pain } \\
\text { anorexia, vomiting }\end{array}$ \\
\cline { 2 - 3 } & Cryptosporidium spp. & \\
\hline
\end{tabular}

Listeria monocytogenes, a notorious food borne pathogen is found in unpasteurized apple juices. Salmonella spp., Escherichia coli $\mathrm{O} 157: \mathrm{H7}$, and Cryptosporidium spp. were also found in unpasteurized juices. Salmonella spp. associated food borne disease outbreak occurred before the $20^{\text {th }}$ century in Sarasota County, Florida and United States. Hepatitis A was occurred in Egypt in 2004 due to intake of fruit juice ${ }^{71}$.

Governing bodies selecting the criteria for quality of fruit juices

According to Fruit Juice and Fruit Nectars (FJFN) Regulations 2013 in England, freezing of fruits before juice production is prohibited, and addition of sugars in juice is also not permitted ${ }^{72}$. According to the opinion of the United State Department of Agriculture (USDA) people consuming 100\% juice does not cause obesity in most cases but obese people may gain weight for drinking of $100 \%$ juice ${ }^{73}$, whereas, the Academy of Nutrition and Dietetics Evidence Analysis Library (ANDEAL) concluded that in case of children there is no interrelation between weight gain and fruit juice consumption ${ }^{74}$. In Ethiopian Public Health Institute (EPHI) Food Microbiology guideline, it has been suggested that people should not be sold or consumed spoiled, poor quality and harmful toxin containing juices. It is prohibited to manufacture, package, handle and store fruit juice in unhygienic condition ${ }^{75}$. According to FDA, fruit juices should be rejected if it contains toxins, high microbial load and high pesticide residue ${ }^{76}$. Microbial limit in fruit juice is listed in Table 3 according to the FDA standard. According to Food Safety and Standard Authority of India (FSSAI, 2011) ${ }^{77}$, microbiological limits are listed in Table 4.

Table 4. Microbial limits in fruit juice

\begin{tabular}{lc}
\hline Microorganism & Maximum limit \\
\hline Total bacterial count $/ \mathrm{ml}$ & 25 \\
Total coliform count $/ 100 \mathrm{ml}$ & Absent \\
Escherichia coli/ $100 \mathrm{ml}$ & Absent \\
Yeast and $\mathrm{mold} / \mathrm{ml}$ & 5 \\
\hline
\end{tabular}

Table 4. Microbiological requirements of Fruit Juices as per FSSAI ( 2011) ${ }^{77}$

\begin{tabular}{lc}
\hline Count $(\mathrm{cfu} / \mathrm{ml})$ & Maximum Count Permitted \\
\hline Total count & Not more than 50 \\
Coliform & Absent in $100 \mathrm{ml}$ \\
Yeasts & Not more than 2 \\
\hline
\end{tabular}

FSSAI (Licensing and Registration of Food businesses) Regulation, $2011^{78}$

Permitted ingredients for juice $\mathrm{FSSAI}^{77}$ include sugar (less than $2 \%$ moisture), liquid sucrose/ invert sugar/ fructose syrup/ liquid cane sugar, lime/lemon juice, salts/spices/ aromatic herbs for tomato juices, vitamins and minerals.

\section{Study carried out in Bangladesh}

From an investigation on the commercially available nine fruit juices of mango and oranges in Bangladesh, it was found that $\mathrm{pH}$ range of the fruit juice samples studied was between $3.50 \pm 0.10$ and $4.70 \pm 0.05$. Vitamin $C$ and protein content were higher in mango juices than orange juices ${ }^{47}$. Heavy metals like arsenic, lead, copper and zinc were within the limits recommended by Bangladesh Standard and Testing Institute (BSTI). and the Gulf standards (the recommended Microbiological Standards for any fruit juice sold in the Gulf Region ${ }^{78}$. In another study, several kinds of fruit juices showed $\mathrm{pH}$, acidity, total aerobic plate count, yeast-mold count, heavy metal content within the standards recommended by Gulf standards, though the preservative content was higher ${ }^{79}$. Both local and foreign packed and commercial juices are available in Bangladesh. Some local brand juices often contain total bacterial count and yeast-mold count above the range of the required limits. Such fruit juices can be responsible for the onset of public health hazards. 


\section{Future aspects of commercial fruit juice and recommendations}

Fruit juice should not be given to infants less than six months old as this might cause allergies, dermatitis, perioral rash, carbohydrate malabsorption, and acute diarrhea. Over consumption of juices by old and children under 5 years old can cause diarrhea, over nutrition, and dental carries. Consuming fruit juice without added sugars is recommended for the people of all ages because of the nutritional values and beneficial effects to our health status. Naturally, fruit juices are good sources of nutrition imparting essential amino acids, vitamins and minerals. Juices can be enjoyed at any corner of the world and at any time upon individual's choice. Immune compromised patients with poor health condition can be given natural antimicrobials, vitamins, necessary amino acids, minerals enriched juices. Fruit juice is a source to get instant energy. Fruit juice is a source to get instant energy. Fruit juice should be made with fresh, washed, and selected fruits to avoid contaminants. During the juice processing, aseptic condition should be strictly maintained. Operators and workers should have the proper knowledge about the personal hygiene, good hygienic practice (GHP) and good manufacturing practice (GMP) and the risk of public health if pathogenic bacteria find their way into the juice.

\section{Conclusion}

Fruit juices are one of the most popular drinks which is beneficial for the people of all ages. They not only fulfill the requirements of our nutritional demands but protect us from a variety of diseases if consumed regularly starting from the early ages. The quality of the fruit juices should be maintained to avoid the chance of food borne disease outbreaks. Though fruit juices make our immune status strong, but it can cause damage if over consumed and/or it is contaminated with food borne pathogens. Quality test should be started from the fruits selected for making juice, harvesting, peeling, processing, and use of additives, packaging materials and storage conditions. Consumer handling is an important factor to reduce the complications of fruit juice consumption.

\section{Acknowledgement}

Authors acknowledge the research groups whose findings have been used to write this article.

\section{Conflict of interest}

Authors have no potential conflict of interest.

\section{References}

1. Raybaudi-Massilia RM, Mosqueda-Melgar J, Soliva-Fortuny R, and Mart'1n-Belloso O. 2009. Control of pathogenic and spoilage microorganisms in fresh-cut fruits and fruit juices by traditional and alternative natural antimicrobials, Comprehensive Reviews. Food Sci. Food Safety., 8(3): 157- 180.

2. Piló FB, Pereira NO, Freitas D, Miranda ND, Carmo SD, Gomes CO, Nardi MD and Rosa CA. 2009. Microbiological testing and physical and chemical analysis of reconstituted fruit juices and coconut water. $J$. Alimentaria Nutria., 20(4): 523-532.
3. USDA and US Department of Health and Human Ser v ices. Dietar y guidelines for Americans, 2010. 7th ed. Washington (DC): US Government Printing Office;

4. Percentage Juice Declaration for Foods Purporting to be Beverages That Contain Fruit or Vegetable Juice, 2013. 21 C.F.R. Sect. 101.30

5. Hornick BA, Weiss L. Comparative nutrient analysis of commonly consumed vegetables. Nutr Today., 46:130-7.

6. Song W, Derito CM, Liu K, He X, Dong M, Liu RH. 2010. Cellular antioxidant activity of common vegetables. J. Agric Food Chem., 58:6621-9.

7. National Nutrient Database for Standard Reference [Internet]. Release 27. Washington (DC): USDA; 2014 [cited 2014 Dec 14]. Available from: http://www.ars.usda.gov/ba/bhnrc/ndl.

8. Drug Dictionar y NCI. 2014. [cited 2015 Jan 23]. Available from: http:/ /www.cancer.gov/drugdictionary cdri $\mathrm{d}=539361$.

9. Amarowicz R, Carle R, Dongowski G, Durazzo A, Galensa R, Kammerer D, Maiani G, Piskula MK. 2009. Influence of postharvest processing and storage on the content of phenolic acids and flavonois in foods. Mol Nutr Food Res., 53 (Suppl 2):S151-83.

10. Manach C, Williamson G, Morand C, Scalbert A, Rémésy C. 2005. Bioavailability and bioefficiency in humans. I. Review of 97 bioavailability studies. Am J Clin Nutr., 81 (Suppl): 230S-42S.

11. Matthews KR. Microorganisms associated with fruits and vegetables, in Microbiology of Fresh Produce, K. R. Matthews, Ed., pp. 1-19, ASM Press, Washington, DC, USA, 2006.

12. Kumar S, Thppareddi H, Subbiah J, Zivanovic S, Davidson PM, and Harte F. 2009. Inactivation of Escherichia coli K-12 in apple juice using combination of high-pressure homogenization and chitosan. J. Food Sci., 74: M8-M14,

13. Patrignani F, Vannini L, Kamdem SLS, Lanciotti R, and Guerzoni ME. 2010. Potentialities of high pressure homogenization to inactivate Zygosaccharomyces bailli in fruit juices. J. Food Sci., 75(2): M116-M120.

14. Mosqueda-Melgar J, Raybaudi-Massilia RM, and Mart'1nBelloso O. 2012. Microbiological shelf life and sensory evaluation of fruit juices treated by high intensity electric filds and antimicrobials. Food and Bioproducts Process., 90(2): 205- 214.

15. International Federation of Fruit Juice Producers Union. 2011. Fruit Juice Nutri. Health-Sci. Rev.

16. Alothman M, Bhat R, Karim AA. 2009. Effects of radiation processing on phytochemicals and antioxidants in plant produce. Trends Food Sci Tech., 20:201 -212.

17. Woods R, Walters H, Raven J, Wolfe R, Ireland P, Thien F, Abramson M. 2003. Food and nutrient intakes and asthma risk in young adults. $A m J$ Clin Nutr., 78:414-421.

18. Willett W. 2002. Balancing life-style and genomics research for disease prevention. Science., 296:695-698.

19. Ames B, Shigenaga M, Hagen T. 1993. Oxidants, antioxidants, and the degenerative diseases of aging. Proc Natl Acad Sci, 90:7915-7922.

20. Hollman P, Katan M. 1997. Absorption, metabolism and health effects of dietary flavonoids in man. Biomed Pharmacother., 51:305-310.

21. Liu RH: Health benefits of fruit and vegetables are from additive and synergistic combinations of phytochemicals. Am J Clin Nutr., 2003, 78(3 Suppl):517S-520S.

22. Liu RH. 2013. Health-Promoting Components of Fruit and vegetables in the Diet. Adv. Nutr., 4: 384S-392S.

23. WHO (World Health Organization). 2002. The world health report 2002 - Reducing risks, promoting healthy life. Geneva WHO.

24. Rasmussen Mette, Krølner Rikke, Klepp Knut-Inge, Lytle Leslie, Brug Johannes, Bere Elling, \& Due P. 2006. Determinants of fruit and vegetable consumption among children and adolescents: a review of the literature. Part I: quantitative studies. International Journal of Behavioral Nutrition 
and Physical Activity 2006 3:22. Retrieved April 29, 2014, from http:// www.ijbnpa.org/content/3/1/22\#

25. OECD. 2013a. Fruit and vegetable consumption among adults, in Health at a Glance 2013: OECD Indicators, OECD Publishing. http://dx.doi.org/ 10.1787/health_glance-2013-22-en

26. OECD. 2013b. Fruit and vegetable consumption among children, in Health at a Glance 2013: OECD Indicators, OECD Publishing. http:// dx.doi.org/10.1787/health_glance-2013-17-en

27. Dubowitz T, Heron M, Bird CE, Lurie N, Finch BK, Basurto-Davila R, et al. 2008. Neighborhood socioeconomic status and fruit and vegetable intake among whites, blacks, and Mexican Americans in the United States. Am J Clin Nutr. 87:1883-91.

28. Hughes RJ, Edwards KL, Clarke GP, Evans CE, Cade JE, Ransley JK. 2012. Childhood consumption of fruit and vegetables across England: a study of 2306 6-7-year-olds in 2007. Br J Nutr., 108:733-42. 10.1017/ S0007114511005939

29. McCabe-Sellers BJ, Bowman S, Stuff JE, Champagne CM, Simpson PM, Bogle ML. 2007. Assessment of the diet quality of US adults in the Lower Mississippi Delta. Am J Clin Nutr., 86:697-706.

30. Loftfield E, Yi S, Curtis CJ, Bartley K, Kansagra SM. 2013. Potassium and fruit and vegetable intakes in relation to social determinants and access to produce in New York City. Am J Clin Nutr., 98:1282-1288.

31. Azagba S, Sharaf MF. 2011. Disparities in the frequency of fruit and vegetable consumption by socio-demographic and lifestyle characteristics in Canada. Nutr J., 10:118. 10.1186/1475-2891-10-118

32. Leung CW, Ding EL, Catalano PJ, Villamor E, Rimm EB, Willett WC. 2012. Dietary intake and dietary quality of low-income adults in the Supplemental Nutrition Assistance Program. Am J Clin Nutr., 96: 977988.

33. Parish ME. 2009. Food safety issues and the microbiology of fruit beverages and bottled water. In: Microbiologically Safe Foods. Heredia, N., Wesley, I. and Garcia, S. (Eds) John Wiley \& Sons: 291-303.

34. Ahmed MSU, Nasreen T, Feroza B and Parveen S. 2009. Microbiological quality of local market vended freshly squeezed fruit juices in Dhaka city, Bangladesh. Bangladesh J Sci. Ind. Res., 44(4): 421-429.

35. Sharma PU. 2013. Bacteriological analysis of street vended fruit juices in Vidharbha. I J Current Microbiol Appl Sci.. 2(5): 178-183.

36. Olorunjuwon BO, Temitope BK, Muibat FO and Afolabi O. 2014. Microbiological quality of some locally produced fruit juices in Ogun state, South Western Nigeria. J Microbiol Res., 2(1): 1-8.

37. Sandeep M, Diwakar A and Abhitjit G. 2001. Microbiological analysis of street vended fresh squeezed carrot and kinnow-mandarian juices in Patiala city, India. Int J Food Safety. 3: 1-3.

38. ICMSF. 2005. Sof drinks, fruit juices, concentrates and food preserves, in MicroorganismsinFoods6:MicrobialEcologyofFood Commodity, Kluwer Academic.

39. Vantarakis A, Affi M, Kokkinos P, Tsibouxi M, and Papapetropoulou M. 2011. Occurrence of microorganisms of public health and spoilage signifiance in fruit juices sold in retail markets in Greece, Anaerobe, 17(6): 288-291.

40. Walker M and Phillips C A.. 2007. Th growth of Propionibacterium cyclohexanicum in fruit juices and its survival following elevated temperature treatments, Food Microbiol., 24(4): 313-318.

41. Walker M and Phillips CA. 2008. The effect of preservatives on Alicyclobacillus acidoterrestris and Propionibacterium cyclohexanicum in fruit juice, Food Cont., 19(10): 974-981.

42. Walker M and Phillips CA. 2008. Alicyclobacillus acidoterrestris: an increasing threat to the fruit juice industry? Int J Food Sci Technol., 43(2): $250-260$.
43. Steyn CE, Cameron M, and Witthuhn RC. 2011. Occurrence of Alicyclobacillus in the fruit processing environment - a review, Int J Food Microbiol., 147(1): 1- 11 .

44. Sospedra J, Rubert J, Soriano M and Manes J. 2012. Incidence of microorganisms from fresh orange juice processed by squeezing machines, Food Cont., 23(1): 282-285.

45. Nicolas B, Razack BA, Yollande I, Aly S, Tidiane OCA, Philippe NA, Comlan DS, Sababénédjo TA. 2007. Street Vended foods improvement: contamination mechanism and application of food safety objective strategy: Critical Review. Pak J Nutr., 6(1): 1-10.

46. Oliveira ACG, Seixas ASS, Sousa CP, Souza CWO. 2006. Microbiological evaluation of sugarcane juice sold at street stands and juice handling conditions in São Carlos, São Paulo, Brazil. Cad Saude Publica., 22(5):1111 -1114.

47. Tasnim F, Hossain MA, Nusrath S, Hossain MK, Lopa D, Haque KMF. 2010. Quality Assessment of Industrially Processed Fruit Juices Available in Dhaka City, Bangladesh. Malaysia J Nutri., 16(3): $431-438$.

48. Chumber SK, Kaushik K, Savy S .2007. Bacteriological analysis of street foods in Pune. Indian J Public Health., 51(2): 114- 116.

49. Noor R. 2016. Microbiological quality of commonly consumed street foods in Bangladesh. Nutri Food Sci. 46(1): 130-141.

50. Rahman H, Feroz F, Alam MS, Das KK, Noor R. 2016. Demonstration of the source of microbial contamination of feshly cultivated cabbage, cauliflower, potato and squash collected from rural farms of Bangladesh. Int Food Res J., 23(3): 1289-1295.

51. Noor R, Feroz F. 2015. Requirements for microbiological quality management of the agricultural products: an introductory review in Bangladesh perspectives. Nutri Food Sci., 45 (5): 808-816.

52. Basar A, Rahman RS (2007) Assessment of Microbiological Quality of Processed Fruit Juice. Bangladesh J Microbiol., 24: 166-168.

53. Rahman T, Hasan S, Noor R (2011) An Assessment of Microbiological Quality of Some Commercially Packed and Fresh Fruit Juice Available in Dhaka City: A Comparative Study. Stamford J Microbiol., 1: 13-18.

54. Braide W, Oranusi, SU, Otali CC (2012) Microbiological status of processed fruit juice sold in the commercial city of Onitsha. Scholarly $J$ Bio Sci., 1: 25-30.

55. Alam MS, Feroz F, Rahman H, Das KK, Noor R. 2015. Microbiological contamination sources of freshly cultivated vegetables. Nutri Food Sci., 45(4): 646-658.

56. Noor R, Uddin MA, Haq MA, Munshi SK, Acharjee M, Raahman MM. 2013. Microbiologicl study of vendor and packed fruit juice locally available in Dhaka city, Bangladesh. Int Food Res J., 20(2): 1011-1015.

57. Acharjee M, Fatema K, Jahan F, Siddique SJ, Uddin MA, Noor R. 2013. Prevalence of Vibrio cholera in different food samples I the city of Dhaka, Bangladesh. Int Food Res J., 20(2): 1017-1022.

58. Hasan MK, Acharjee M, Das E, Das KK, Ahmed T, Akond MA, Fatema KK, Noor R. 2013. Microbiological study of sean fish samples collected from local markets in Dhaka City. Int Food Res J., 20(3): 1491-1495.

59. Feroz F, Senjuti JD, Noor R. 2013. Determination of microbial growth and survival in salad vegetables through in vitro challenge test. Int J Nutri Food Sci., 2(6): 312-319.

60. Arias CR, Burns JK, Friedrich LM, Goodrich RM and Parish ME. 2002. Yeast species associated with orange juice: evaluation of diffrent identifiation methods, Appl Env Microbiol., 68(4): 1955-1961.

61. Stratford M. 2006. Food and beverage spoilage yeasts," in Yeasts in Food and Beverages Handbook, G. M. Fleet and A. Querol, Eds., Berlin, Germany, pp. 335-379, Springer.

62. Lenovich LM, Buchanan RL,NJ Worley and Restaino L. 2006. Effct of solute on sorbate resitsance in Zygosaccharomyces rouxii, J Food Sci., 53: 914-916. 
63. K. A. Lawlor, J. D. Schuman, P. G. Simpson, and P. J. Taormina. 2009. Microbiological spoilage of beverages. in Compendium Microbiol Spoilage of Foods and Beverages, W. H. Sperber and M. P. Doyle, Eds., Food Microbiology and Food Safety, Springer Science and Business Media, New York, NY, USA,

64. Lawlor KA, Schuman JD, Simpson PG and Taormina PJ. 2009. Microbiological spoilage of beverages, in Compendium of the Microbiological Spoilage of Foods and Beverages, W. H. Sperber and M. P. Doyle, Eds., Food Microbiology and Food Safety, Springer Science and Business Media, New York, NY, USA.

65. Williams RC, Sumner SS and Golden DA. 2005. Inactivation of Escherichia coli O157:H7 and Salmonella in apple cider and orange juice treated with combinations of ozone, dimethyl dicarbonate, and hydrogen peroxide. J. Food Sci., 70:197-201.

66. Yuste J and Fung DYC. 2004. Inactivation of Salmonella Typhimurium and Escherichia coli $\mathrm{O} 157: \mathrm{H} 7$ in apple juice by a combination of nisin and cinnamon. J. Food Prot., 67:371-377.

67. Zhao T, Doyle MP and Besser RE. 1993. Fate of enterohemorrhagic Escherichia coli O157:H7 in apple cider with and without preservatives. Appl. Env. Microbiol., 59:2526-2530.

68. Baumann AR, Martin SE and Feng H. 2005. Power ultrasound treatment of Listeria monocytogenes in apple cider. J. Food Prot. 68:2333-2340.

69. Gérard Krause MD, Robin M, Terzagian, Hammond R. 2001. Outbreak of Salmonella Serotype Anatum Infection Associated With Unpasteurized Orange Juice. South Med J., 94(12): 1168-1172.

70. Krause G, Terzagian R, Hammond R. 2001. Outbreak of Salmonella serotype Anatum infection associated with unpasteurized orange juice. South Med J., 94: 1168-72.

71. Frank C, Walter J, Muehlen M, Jansen A, Treeck U, Hauri AM, Zoellner I, Rakha M, Hoehne M, Hamouda O, Schreier E and Stark K. 2007. Major
Outbreak of Hepatitis A Associated with Orange Juice among Tourists, Egypt, 2004. CDC. Emerging Infectious Diseases. Volume 13, Number 1-January 2007

72. The Fruit Juices and Fruit Nectars (England) Regulations 2013. No. 2775. Regulation 6.

73. USDA and US Department of Health and Human Services. 2010. Dietar y guidelines for Americans, 2010. 7th ed. Washington (DC): US Government Printing Office;

74. Academy of Nutr ition and Dietetics Evidence Analysis Library [Internet]. Dietary and Metabolic Impact of Fruit Juice Consumption Evidence Analysis Project. Chicago: Academy of Nutrition and Dietetics; 2014 [cited 2014 Jul 1]. Available from: http://andevidencelibrary.com/ topic.com?cat $=5113$.

75. Kiiyukia C. 2003. UNIDO Project, Laboratory Manual of Food Microbiology for Ethiopia Health and Nutrition Research Institute. YA/ ETH/03/436/11-52

76. HACCP. 2000. Quality Control/Quality Assurance and International Trade; Good Manufactug. P.G Practices (Gmp). Hygiene Requirements.

77. Food Safety and Standards (Licensing and Registration of Food businesses) Regulation, 2011.

78. Tasnim F, Anwar Hossain M, Nusrath S, Kamal Hossain M, Lopa D \& Formuzul Haque KM. 2010. Quality Assessment of Industrially Processed Fruit Juices Available in Dhaka City, Bangladesh. Industrially Processed Fruit Juices Available in Dhaka City, Bangladesh. Mal J Nutr., 16(3): $431-438$

79. Kayshar MS, Saifullah M, Rahman A and Uddin MB. 2014. An overview of quality status of selected commercial brands of juices and jams based on public perception and laboratory analysis. J. Bangladesh Agril. Univ., 12(1): $183-188$ 